\title{
On The Cost Implications of Technical Energy Losses on Nigerian 330-kV Transmission Grid System
}

\author{
Ademola Abdulkareem ${ }^{1}$, Awosope Claudius², Ayokunle Awelewa ${ }^{3}$ \\ ${ }^{1,2,3}$ Electrical and Information Engineering Department, College of Engineering, Covenant University, Ota, Nigeria
}

\begin{abstract}
Base on the author's result of power line losses obtained for low, medium and high current levels as 146.73MW, 322.24MW and $738.28 \mathrm{MW}$ respectively, in his bid to evaluate the power line losses using symmetrical component theory of unbalanced fault, the annual energy (MWH) losses for year 2013 was calculated and validated in this study. The annual technical energy losses due to the low, medium and high power losses were respectively found to be 443.45GWH, 976.895GWH and 2231.230GWHbased on Load Factor and Load Loss Factor amounting to N8.4 billion, N18.6 billion and N42.4 billion respectively. The low power loss (steady-state) result of this work was validated by the result of load-flow obtained using the MATLAB and Power Word Simulator (PWS) while the annual MWH for the high power loss level compares favourably well with the normal practice of utility operator's monthly energy balance thereby closing the gap between the practical information and the theoretical one.
\end{abstract}

Keywords: Power line losses, Current levels, Load Factor, Load Loss Factor, Load-Flow

\section{Introduction}

Power quality has become an important issue for maximum efficiency operation of energy that is delivered to transmission and distribution line. The more the power that flows through the network, the more the current and hence the voltage drop becomes more excessive and power quality declines. The global problem of the lower power availability to consumers is a consequence of power loss and no matter how carefully the power system network is designed, losses are inevitable. Loss of power on transmission lines is a global problem and it is necessary to state here that the losses on transmission lines can result into line outages in the electric power system. The existing transmission system in Nigeria is characterized by high line losses and several outages leading to interruption of systems and equipment. Nigerian electricity grid has a large proportion of transmission and distribution losses, and these amounts to a whopping $44.5 \%$ of generation [1]. Based on the Power Holding Company of Nigeria (PHCN) annual reports for the 2004 and 2005, the transmission line losses alone were estimated to be $9.2 \%$ [2]. Countries such as China that have attached importance to loss minimization to enhance efficiency have about $13 \%$ transmission and distribution losses with India having about 23\% [3]. The losses in some other countries like Iraq, Moldova, Sudan, Venezuelan RB, Syria, Korea Republic, Yemen Republic, Pakistan, Tanzania, México, Taiwan, U.S.A, and Japan are 42, 40, 28, 27, 26, 25, 22, $20,16,9,6$ and $5 \%$ respectively [4].

However, going by the available data and tools needed for calculating technical losses in power system, current techniques have certain drawbacks regarding such calculations.Moreover, literature reveals different methods of loss estimation but the existing approaches focus mainly on theoretical calculation and probabilistic data that are based on simple model data, insufficient to give a correct evaluation assessment of losses [5]. Hence, there is still a clear gap between practical information and the theoretical one which tends to be poor and not precise [6] and the reduction of system losses is analyzed on the accuracy of the technical losses. To solve the challenging problems inherent in designing future power systems to deliver increasing amounts of electrical energy in a safe, clean and economical manner [7], a regular and fairly accurate description of power losses as a function of time to make a reliable prediction of energy losses is required. The objective of this study, therefore, is to evaluate the technical losses in and its cost implication on Nigeria 330$\mathrm{kV}$ power transmission system.

\section{Methodology}

The methodology adopted for this study is the analysis of the disturbances brought about by the faults followed by the procedure for maximum line currents determination that is used to calculate the power losses and the values are used thereafter to evaluate the annual energy losses and its cost implications in the Nigeria $330-\mathrm{kV}$ power transmission system. Results analysis of load-flows using the code-based MATLAB and Power World Simulation model-based software are presented and discussed.

\subsection{Disturbances in Nigeria 330-kV Transmission System}

Table 2.1 gives the summary of the yearly energy balance that reflects a total loss of $14204.74 \mathrm{GWH}$ from 2005 to 2011 as reported in the PHCN monthly energy balance summary.. These transmission losses - calculated to be approximately $10.05 \%$ of the energy fed into the grid [8], clearly show that majority of the outages in NESI are responsible for the problem in the transmission network. 


\section{International Journal of Science and Research (IJSR) \\ ISSN (Online): 2319-7064}

Index Copernicus Value (2013): 6.14 | Impact Factor (2014): 5.611

Table, 2.1: (Yearly energy balance summary 2005-2011

\begin{tabular}{|c|c|c|c|c|}
\hline Year & $\begin{array}{c}\text { Energy Delivered to Transmission } \\
\text { Line }(G W H)\end{array}$ & $\begin{array}{c}\text { Energy Available for } \\
\text { Sale }(G W H)\end{array}$ & $\begin{array}{c}\text { Transmission Line energy } \\
\text { Losses }(G W H)\end{array}$ & $\begin{array}{c}\text { Line Losses Percentage of Energy } \\
\text { Delivered }(\%)\end{array}$ \\
\hline 2005 & $23,403.26$ & $21,401.87$ & $2,001.39$ & 8.55 \\
\hline 2006 & $22,576.02$ & $21,024.39$ & $1,551.63$ & 6.87 \\
\hline 2007 & $22,255.76$ & $20,419.07$ & $1,836.69$ & 8.25 \\
\hline 2008 & $20,765.71$ & $18,885.51$ & $1,880.19$ & 9.05 \\
\hline 2009 & $20,329.45$ & $18,620.10$ & $1,709.35$ & 8.41 \\
\hline 2010 & $24,362.42$ & $2,1931.67$ & $2,430.75$ & 9.98 \\
\hline 2011 & $26,999.35$ & $24,204.62$ & $2,794.73$ & 10.35 \\
\hline \multicolumn{2}{|r|}{ Total: $\mathbf{1 6 0 , 6 9 1 . 9 7}$} & $\mathbf{1 4 , 2 0 4 . 7 4}$ & $\mathbf{8 . 8 4}$ \\
\hline
\end{tabular}

\subsection{Overview of the Nigerian 330-kV Transmission Network}

The Nigerian Transmission system is made up of interconnected network of $5,650 \mathrm{~km}$ of $330 \mathrm{kV}$ that spans the country nationwide. The single-line diagram of the Nigerian 330-kV network currently consists of sixty 330$\mathrm{kV}$ transmission line circuits, eight effective generating stations, twenty load stations, twenty-eight buses (substations), and thirty-three transmission lines as shown in figure 2.1
The system may be divided into three geographical zonesNorth, South-East, and the South-West. The North is connected to the South through the one-triple circuit lines between Jebba and Oshogbo while the West is linked to the East through one transmission line from Oshogbo to Benin and one double line from Ikeja to Benin. The transmission grid is centrally controlled from the National Control centre (NCC) located at Oshogbo in Osun State, while there is a back-up or Supplementary National Control Centre (SNCC) at Shiroro in Niger State. In addition to these two centres are three Regional Control Centres (RCCs) located at Ikeja West (RCC1), Benin (RCC2) and Shiroro (RCC3) substations [9].

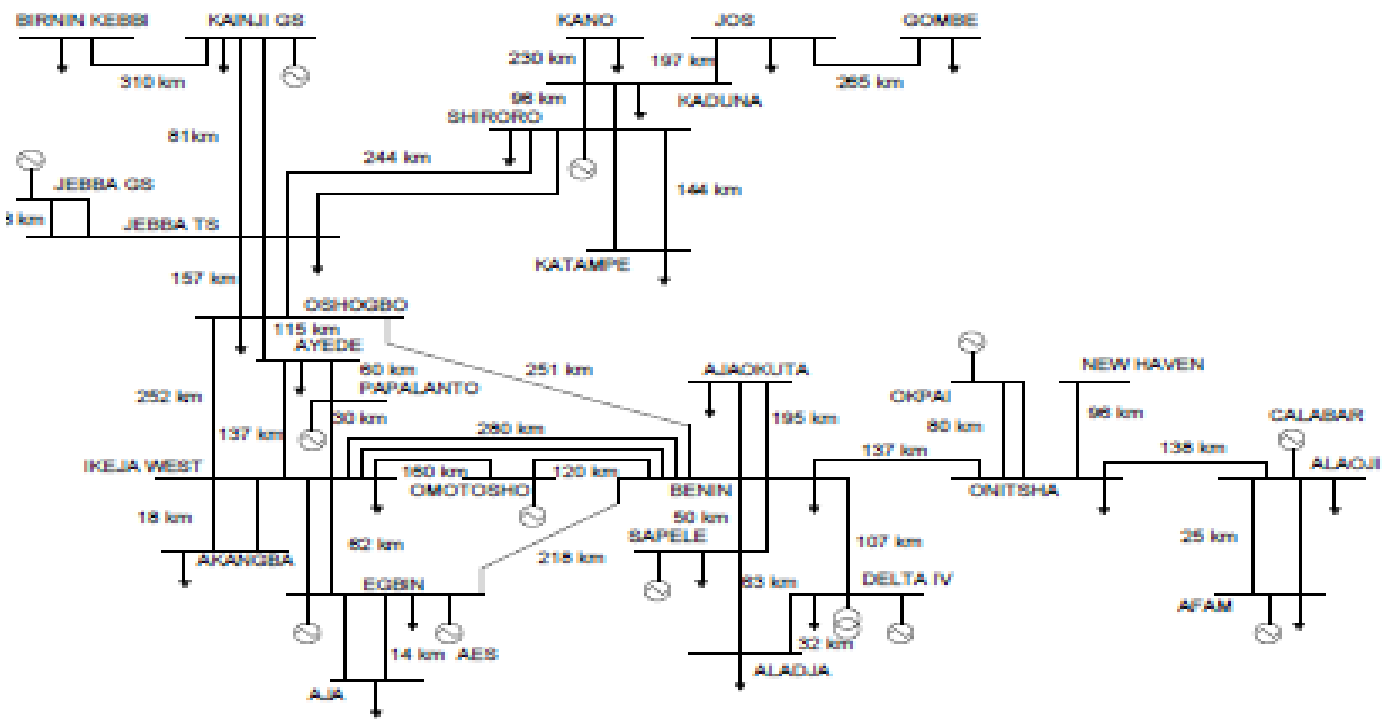

Figure 2.1: The Nigerian 330-kV Transmission System

\section{Results and Discussion}

\subsection{Load-Flow Analysis of the Existing Nigerian 330- kV Transmission Network}

In order to perform a power flow analysis using the Newton-Raphson (N-R) method program in the MATLAB environment, the one-line diagram of the existing Nigerian $330 . \mathrm{kV}$ network is redrawn using E-draw max as shown in figure 2.1 for clear identification of buses and branches in the network. This study is carried out majorly using statistical measures of central tendency to analyse data gotten from the nation's National Control Centre (NCC),
Oshogbo and some of the generating stations in the country [10].

However, from the convergence of N.R load-flow results of table 3.1, a summarized result of active power, reactive power and complex power flow at each bus and the line flow is as presented in table 3.1. The total active power loss from the power flow program solutions by NewtonRaphson method is 203.620 MW and that of the reactive power loss is -1556.448 Mvar. 


\section{International Journal of Science and Research (IJSR) \\ ISSN (Online): 2319-7064}

Index Copernicus Value (2013): 6.14 | Impact Factor (2014): 5.611

Table 3.1: Summary of load-flow results of N-R

\begin{tabular}{|c|c|c|c|c|c|c|}
\hline From Bus & To Bus & $\begin{array}{c}\text { Active Power flow } \\
(M W)\end{array}$ & $\begin{array}{c}\text { Reactive Power flow } \\
\text { (Mvar) }\end{array}$ & $\begin{array}{c}\text { Complex Power flow } \\
(M V A)\end{array}$ & $\begin{array}{c}\text { Active Power loss } \\
(M W)\end{array}$ & $\begin{array}{c}\text { Reactive Power loss } \\
\text { (Mvar) }\end{array}$ \\
\hline 1 & 2 & 115.9879 & -30.7254 & 119.9885 & 1.4879 & -116.625 \\
\hline 1 & 3 & 501.7121 & -55.2062 & 504.7403 & 6.633 & -11.5062 \\
\hline 2 & 1 & -114.5 & -85.9 & 143.14 & 1.4879 & -116.625 \\
\hline 3 & 1 & -495.079 & 43.7 & 497.0041 & 6.633 & -11.5062 \\
\hline 3 & 4 & -494.329 & -38.5246 & 495.8279 & 0.671 & -2.3843 \\
\hline 3 & 5 & 321.8366 & 13.46 & 322.1179 & 5.6016 & -78.1002 \\
\hline 3 & 23 & 656.5715 & -26.8354 & 657.1197 & 26.6503 & 75.2551 \\
\hline 4 & 3 & 495 & 36.1403 & 496.3176 & 0.671 & -2.3843 \\
\hline 5 & 3 & -316.235 & -91.5602 & 329.2231 & 5.6016 & -78.1002 \\
\hline 5 & 6 & 177.026 & 42.3656 & 182.0249 & 1.5765 & -71.7504 \\
\hline 5 & 8 & 128.921 & 11.3987 & 129.4239 & 1.0055 & -93.4136 \\
\hline 5 & 13 & -190.912 & -113.1042 & 221.9008 & 3.238 & -172.5968 \\
\hline 6 & 5 & -175.4496 & -114.116 & 209.2965 & 1.5765 & -71.7504 \\
\hline 6 & 7 & -80.9763 & -36.6775 & 88.8954 & 0.1617 & -34.9959 \\
\hline 6 & 8 & -19.3741 & -56.0066 & 59.2629 & 0.0222 & -98.1078 \\
\hline 7 & 6 & 81.138 & 1.6816 & 81.1554 & 0.1617 & -34.9959 \\
\hline 7 & 8 & 73.662 & -1.6816 & 73.6812 & 0.0577 & -17.1578 \\
\hline 8 & 5 & -127.9155 & -104.8124 & 165.3723 & 1.0055 & -93.4136 \\
\hline 8 & 6 & 19.3963 & -42.1012 & 46.3544 & 0.0222 & -98.1078 \\
\hline 8 & 7 & -73.6044 & -15.4763 & 75.2138 & 0.0577 & -17.1578 \\
\hline 8 & 9 & 247.6955 & 235.7035 & 341.9199 & 2.9955 & -22.7965 \\
\hline 8 & 10 & -403.8922 & -362.0502 & 542.4106 & 6.4373 & 2.3304 \\
\hline 8 & 12 & -44.8346 & -59.1121 & 74.1915 & 1.2761 & -96.9254 \\
\hline 8 & 13 & -250.0452 & -126.1513 & 280.0656 & 6.7175 & -147.3841 \\
\hline 9 & 8 & -244.7 & -258.5 & 355.9499 & 2.9955 & -22.7965 \\
\hline 10 & 8 & 410.3295 & 364.3806 & 548.7654 & 6.4373 & 2.3304 \\
\hline 10 & 11 & 276.706 & 169.1378 & 324.3051 & 2.306 & -36.6622 \\
\hline 10 & 13 & -196.7158 & 18.1493 & 197.5513 & 2.8778 & -27.954 \\
\hline 11 & 10 & -274.4 & -205.8 & 343 & 2.306 & -36.6622 \\
\hline 12 & 8 & 46.1107 & -37.8133 & 59.6326 & 1.2761 & -96.9254 \\
\hline 12 & 13 & 54.4893 & 37.8133 & 66.3244 & 0.3626 & -83.348 \\
\hline 13 & 5 & 194.15 & -59.4926 & 203.0606 & 3.238 & -172.5968 \\
\hline 13 & 8 & 256.7627 & -21.2328 & 257.6391 & 6.7175 & -147.3841 \\
\hline 13 & 10 & 199.5937 & -46.1033 & 204.8491 & 2.8778 & -27.954 \\
\hline 13 & 12 & -54.1266 & -121.1613 & 132.7018 & 0.3626 & -83.348 \\
\hline 13 & 14 & 14.1681 & -155.6499 & 156.2934 & 0.3681 & -165.9499 \\
\hline 13 & 15 & -262.4152 & -26.9578 & 263.7962 & 1.1368 & -36.8382 \\
\hline 13 & 16 & -473.9006 & 20.0871 & 474.3261 & 4.7811 & -12.9197 \\
\hline 13 & 18 & -257.5321 & 123.0107 & 285.4022 & 4.4327 & -70.3566 \\
\hline 14 & 13 & -13.8 & -10.3 & 17.22 & 0.3681 & -165.9499 \\
\hline 15 & 13 & 263.552 & -9.8805 & 263.7372 & 1.1368 & -36.8382 \\
\hline 15 & 17 & -93.852 & 3.7389 & 93.9265 & 0.2026 & -50.8631 \\
\hline 16 & 13 & 478.6817 & -33.0068 & 479.8183 & 4.7811 & -12.9197 \\
\hline 16 & 17 & 191.3183 & -28.4304 & 193.4192 & 0.7637 & -46.2284 \\
\hline 17 & 15 & 94.0547 & -54.602 & 108.755 & 0.2026 & -50.8631 \\
\hline 17 & 16 & -190.5547 & -17.798 & 191.384 & 0.7637 & -46.2284 \\
\hline 18 & 13 & 261.9648 & -193.3673 & 325.6017 & 4.4327 & -70.3566 \\
\hline 18 & 19 & -703.8188 & 82.449 & 708.6316 & 46.1812 & 14.2387 \\
\hline 18 & 20 & 178.7979 & 112.9396 & 211.4806 & 1.7979 & -20.4604 \\
\hline 18 & 22 & 78.4561 & -140.4214 & 160.8525 & 7.0193 & -97.1128 \\
\hline 19 & 18 & 750 & -68.2103 & 753.0954 & 46.1812 & 14.2387 \\
\hline 20 & 18 & -177 & -133.4 & 221.6406 & 1.7979 & -20.4604 \\
\hline 21 & 22 & 378.5 & 359.6307 & 522.1077 & 22.9367 & -3.8779 \\
\hline 22 & 18 & -71.4367 & 43.3086 & 83.5394 & 7.0193 & -97.1128 \\
\hline 22 & 21 & -355.5633 & -363.5086 & 508.4916 & 22.9367 & -3.8779 \\
\hline 23 & 3 & -629.9212 & 102.0904 & 638.1404 & 26.6503 & 75.2551 \\
\hline 23 & 24 & 294.9635 & 64.7522 & 301.9873 & 4.8635 & -80.2478 \\
\hline 23 & 25 & 653.5577 & 486.4913 & 814.7463 & 21.1085 & 145.1124 \\
\hline 24 & 23 & -290.1 & -145 & 324.3193 & 4.8635 & -80.2478 \\
\hline 25 & 23 & -632.4492 & -341.3789 & 718.7013 & 21.1085 & 145.1124 \\
\hline 25 & 26 & 230.5674 & 155.9158 & 278.3362 & 9.9674 & 13.0158 \\
\hline 25 & 27 & 208.8818 & 40.7631 & 212.8221 & 4.8743 & -25.2542 \\
\hline 26 & 25 & -220.6 & -142.9 & 262.8398 & 9.9674 & 13.0158 \\
\hline 27 & 25 & -204.0075 & -66.0173 & 214.4233 & 4.8743 & -25.2542 \\
\hline
\end{tabular}

Volume 5 Issue 1, January 2016 www.ijsr.net 


\section{International Journal of Science and Research (IJSR) \\ ISSN (Online): 2319-7064}

Index Copernicus Value (2013): 6.14 | Impact Factor (2014): 5.611

Another load-flow analysis was carried out on the same $330-\mathrm{kV}$ transmission network (for the purpose of comparison) using the run mode of power world simulator [11]. The line flows and power losses are as presented in table 3.2. The load-flow is performed at a steady state and therefore these results are obtained under normal condition. The load-flow analysis was performed at a steady state; the power-flow solution results obtained for PWS and MATLAB software are compared with the results of low power obtained from LC that is likened to the current that flows under a steady-state condition for validation.

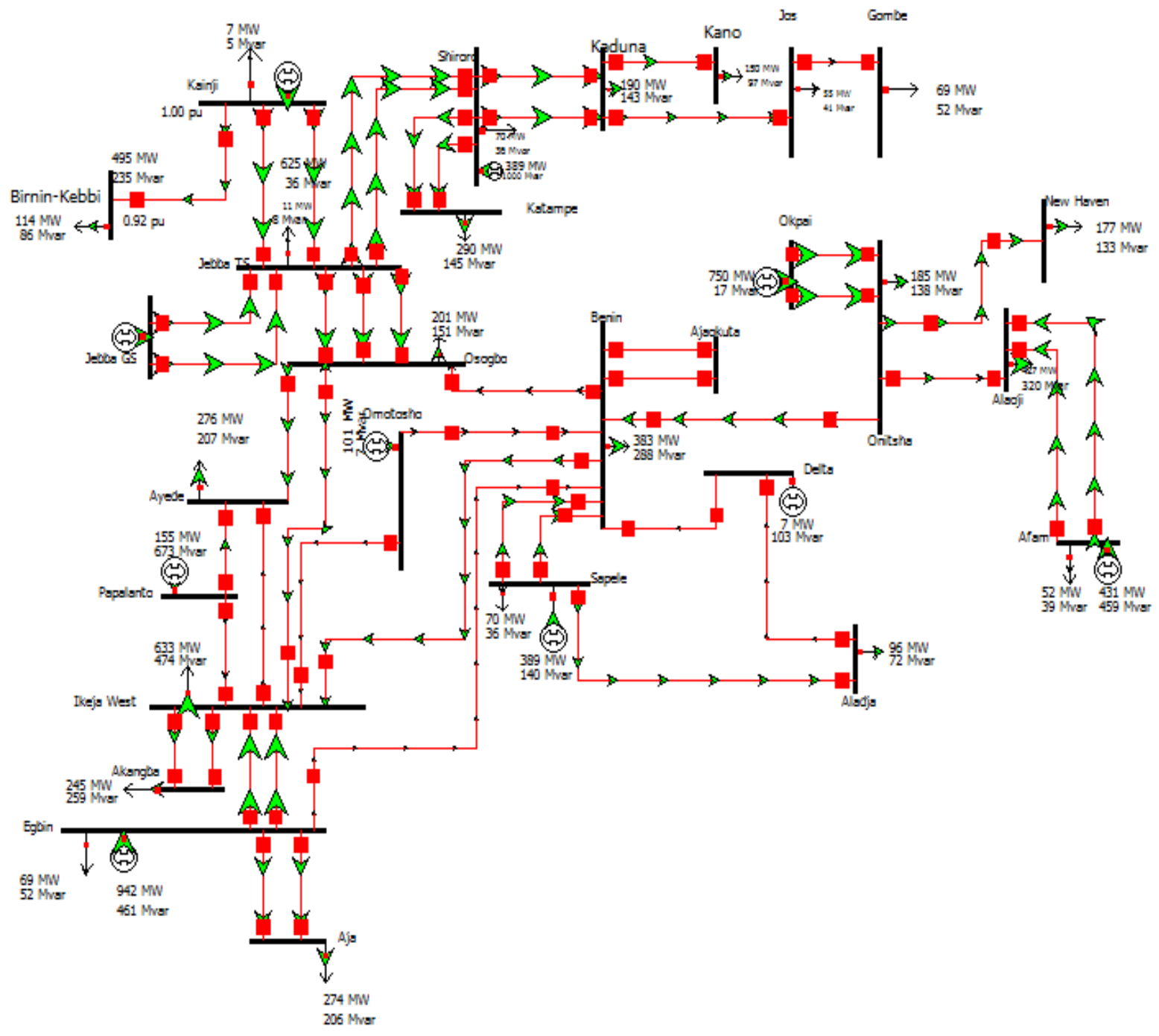

Figure 3.1: The Simulation run Mode of Existing Nigerian 330-kV Transmission Network

Table 3.2: Line-Flows and Power losses for PWS Model-Based Network

\begin{tabular}{|c|c|c|c|c|c|c|c|c|c|}
\hline $\begin{array}{c}\text { From } \\
\text { Bus No }\end{array}$ & From Name & $\begin{array}{c}\text { To } \\
\text { Bus } \\
\text { No }\end{array}$ & To Name & Circuit & MW From & $\begin{array}{c}\text { Mvar } \\
\text { From }\end{array}$ & $\begin{array}{c}\text { MVA } \\
\text { From }\end{array}$ & MW Loss & Mvar Loss \\
\hline 1 & Kainji & 2 & Birnin-Kebbi & 1 & 116.7 & 48.5 & 126.4 & 2.2 & -37.42 \\
\hline 1 & Kainji & 3 & Jebba TS & 1 & 250.5 & -36.7 & 253.2 & 1.83 & -15.25 \\
\hline 1 & Kainji & 3 & Jebba TS & 2 & 250.5 & -36.7 & 253.2 & 1.83 & -15.25 \\
\hline 3 & Jebba TS & 4 & Jebba GS & 1 & -247.3 & 31.8 & 249.4 & 0.19 & -2.07 \\
\hline 3 & Jebba TS & 4 & Jebba GS & 2 & -247.3 & 31.8 & 249.4 & 0.19 & -2.07 \\
\hline 3 & Jebba TS & 5 & Oshogbo & 1 & 116.7 & -10.7 & 117.2 & 0.78 & -52.18 \\
\hline 3 & Jebba TS & 5 & Oshogbo & 2 & 116.7 & -10.7 & 117.2 & 0.78 & -52.18 \\
\hline 3 & Jebba TS & 5 & Oshogbo & 3 & 116.7 & -10.7 & 117.2 & 0.78 & -52.18 \\
\hline 3 & Jebba TS & 23 & Shiroro & 1 & 315.5 & -41.3 & 318.1 & 6.67 & -22.81 \\
\hline 3 & Jebba TS & 23 & Shiroro & 2 & 315.5 & -41.3 & 318.1 & 6.67 & -22.81 \\
\hline 5 & Oshogbo & 6 & Ayede & 1 & 192.3 & 3.5 & 192.3 & 1.59 & -28.35 \\
\hline 5 & Oshogbo & 8 & Ikeja-West & 1 & 130 & -9.9 & 130.4 & 1 & -48.67 \\
\hline 5 & Oshogbo & 13 & Benin & 1 & -175.8 & -20 & 176.9 & 2.89 & -68.38 \\
\hline 6 & Ayede & 7 & Papalanto & 1 & -70.7 & -153.2 & 168.7 & 0.6 & -13.71 \\
\hline
\end{tabular}

Volume 5 Issue 1, January 2016 


\section{International Journal of Science and Research (IJSR) \\ ISSN (Online): 2319-7064}

Index Copernicus Value (2013): 6.14 | Impact Factor (2014): 5.611

\begin{tabular}{|c|c|c|c|c|c|c|c|c|c|}
\hline 6 & Ayede & 8 & Ikeja-West & 1 & -14.4 & -21.8 & 26.1 & 0.01 & -49.07 \\
\hline 7 & Papalanto & 8 & Ikeja-West & 1 & 83.5 & 303.9 & 315.1 & 1.02 & 0.24 \\
\hline 8 & Ikeja-West & 9 & Akangba & 1 & 123.1 & 111.1 & 165.8 & 0.71 & -18.1 \\
\hline 8 & Ikeja-West & 9 & Akangba & 2 & 123.1 & 111.1 & 165.8 & 0.71 & -18.1 \\
\hline 8 & Ikeja-West & 10 & Egbin & 1 & -195.9 & -144.2 & 243.3 & 1.3 & -14.55 \\
\hline 8 & Ikeja-West & 10 & Egbin & 2 & -195.9 & -144.2 & 243.3 & 1.3 & -14.55 \\
\hline 12 & Omotosho & 8 & Ikeja-West & 1 & 44.5 & -15.2 & 47 & 0.12 & -39.71 \\
\hline 8 & Ikeja-West & 13 & Benin & 1 & -246 & -13.8 & 246.4 & 6.53 & -43.48 \\
\hline 10 & Egbin & 11 & Aja & 1 & 137.6 & 82.5 & 160.5 & 0.62 & -20.39 \\
\hline 10 & Egbin & 11 & Aja & 2 & 137.6 & 82.5 & 160.5 & 0.62 & -20.39 \\
\hline 10 & Egbin & 13 & Benin & 1 & -247.3 & 52.6 & 252.8 & 5.1 & 19.63 \\
\hline 10 & Egbin & 29 & AES & 1 & 0 & 0 & 0 & 0 & 0 \\
\hline 12 & Omotosho & 13 & Benin & 1 & 56.1 & -0.6 & 56.1 & 0.15 & -36.88 \\
\hline 13 & Benin & 14 & Ajaokuta & 1 & 7 & -68.7 & 69.1 & 0.08 & -73.86 \\
\hline 13 & Benin & 14 & Ajaokuta & 2 & 7 & -68.7 & 69.1 & 0.08 & -73.86 \\
\hline 13 & Benin & 15 & Sapele & 1 & -145.6 & -54.3 & 155.4 & 0.42 & -17.34 \\
\hline 13 & Benin & 15 & Sapele & 2 & -145.6 & -54.3 & 155.4 & 0.42 & -17.34 \\
\hline 13 & Benin & 16 & Delta & 1 & -445 & 14.4 & 445.3 & 4.65 & 14.76 \\
\hline 13 & Benin & 18 & Onitsha & 1 & -288.7 & 91.3 & 302.8 & 4.84 & -8.72 \\
\hline 15 & Sapele & 17 & Aladja & 1 & -122.3 & 38 & 128.1 & 0.4 & -20.43 \\
\hline 16 & Delta & 17 & Aladja & 1 & 220.3 & -0.5 & 220.3 & 1.12 & -14.5 \\
\hline 19 & Okpai & 18 & Onitsha & 1 & 375 & 23 & 375.7 & 12.73 & -0.14 \\
\hline 19 & Okpai & 18 & Onitsha & 2 & 375 & 23 & 375.7 & 12.73 & -0.14 \\
\hline 18 & Onitsha & 20 & New Haven & 1 & 178.6 & 116.6 & 213.3 & 1.6 & -16.81 \\
\hline 18 & Onitsha & 22 & Alaoji & 1 & 67.8 & -108.8 & 128.2 & 6.17 & -43.72 \\
\hline 22 & Alaoji & 21 & Afam & 1 & -182.7 & -192.6 & 265.5 & 6.57 & -4.98 \\
\hline 22 & Alaoji & 21 & Afam & 2 & -182.7 & -192.6 & 265.5 & 6.57 & -4.98 \\
\hline 23 & Shiroro & 24 & Katampe & 1 & 146.3 & 27.5 & 148.9 & 1.27 & -44.99 \\
\hline 23 & Shiroro & 24 & Katampe & 2 & 146.3 & 27.5 & 148.9 & 1.27 & -44.99 \\
\hline 23 & Shiroro & 25 & Kaduna & 1 & 321.8 & 220.8 & 390.2 & 5.46 & 13.19 \\
\hline 23 & Shiroro & 25 & Kaduna & 2 & 321.8 & 220.8 & 390.2 & 5.46 & 13.19 \\
\hline 25 & Kaduna & 26 & Kano & 1 & 229.1 & 151.6 & 274.7 & 8.48 & 8.72 \\
\hline 25 & Kaduna & 27 & Jos & 1 & 210.5 & 118.8 & 241.7 & 5.5 & -9.88 \\
\hline \multirow[t]{2}{*}{27} & Jos & 28 & Gombe & 1 & 134.7 & 76 & 154.7 & 4.12 & -21.87 \\
\hline & & & & & & & & 136.13 & -1057.4 \\
\hline
\end{tabular}

\subsection{Procedure for Maximum Line Currents}

\section{Determination on the Test System}

The results of all the line current magnitudes obtained in the simulation of various aspects of faults on the threephase power line of the test system are analysed or streamlined in order to rigorously establish a categorical data of maximum line current magnitudes. The results of this analysis are generated for two scenarios: case 1 is when the fault impedance is 0.1 and case 2 when the fault impedance is set to zero.
The case 2 (i.e. $Z_{f}=0$ ) is one extreme considered in the determination of maximum current on the test system and it forms the category that creates tremendous amount of current comparable to the maximum current of the fault impedance, $Z_{f}=0.1$. A tabular summary and graphical representation of the results obtained for the two configurations are presented in tables 3.3 and 3.4 for $\mathrm{Z}_{\mathrm{f}}=$ $\mathrm{j} 0.1$ and for $\mathrm{Z}_{\mathrm{f}}=\mathrm{j} 0$ respectively for the line current magnitude to determine the available maximum current on each line for all the various types of asymmetrical fault considered. The faulted bus locations that cause the maximum current are also presented. Tables 3.3 and 3.4 presentlocation and the corresponding maximum line current that is available on the three-phase line of the test system when SLG, LL and DLG faults are simulated with fault impedances of $\mathrm{j} 0.1$ and $\mathrm{j} 0$ respectively. 


\section{International Journal of Science and Research (IJSR) \\ ISSN (Online): 2319-7064}

Index Copernicus Value (2013): 6.14 | Impact Factor (2014): 5.611

Table 3.3: Maximum line current caused by SLG, LL, DLG and Location when $Z_{\mathrm{f}}=\mathrm{j} 0.1$

\begin{tabular}{|c|c|c|c|c|c|c|}
\hline $\begin{array}{c}\text { From - To } \\
\text { bus }\end{array}$ & $S L G(p u)$ & Location & $L-L(p u)$ & Location & $D L G(p u)$ & Location \\
\hline $1-2$ & 4.7596 & BirninKebbi & 7.1658 & BirninKebbi & 8.973 & BirninKebbi \\
\hline $3-1$ & 8.5218 & JebbaTs & 3.1828 & Kainji & 9.3828 & Kainji \\
\hline $4-3$ & 16.4165 & Oshogbo & 3.2043 & JebbaTs & 5.615 & JebbaTs \\
\hline $5-3$ & 10.3361 & JebbaTs & 3.7182 & Kainji & 3.7935 & JebbaTs \\
\hline $6-5$ & 11.4695 & Papalanta & 3.5445 & Ayede & 5.831 & Ayede \\
\hline $7-6$ & 7.5392 & Akangba & 1.4389 & Papalanto & 3.2273 & Ikeja West \\
\hline $8-6$ & 12.0213 & Papalanto & 3.5589 & Ayede & 5.6907 & Ayede \\
\hline $8-7$ & 7.6034 & Papalanto & 1.0787 & Osogbo & 3.6238 & Ayede \\
\hline $8-5$ & 23.9129 & Ikeja West & 6.2204 & Papalanto & 10.541 & Papalanto \\
\hline $8-9$ & 12.4105 & Egbin & 4.6204 & Akangba & 7.3992 & Akangba \\
\hline $10-8$ & 11.3709 & Akangba & 3.3964 & Ikeja West & 5.3705 & Ikeja West \\
\hline $10-11$ & 14.2855 & Omotosho & 4.7743 & Aja & 7.8635 & Aja \\
\hline $12-8$ & 2.1338 & Sapele & 8.3932 & Ajaokuta & 8.3932 & Benin \\
\hline $12-13$ & 4.3169 & Benin & 4.4479 & Omotosho & 4.3787 & Ajaokuta \\
\hline $13-10$ & 9.7498 & Aja & 7.7994 & Ajaokuta & 7.7994 & Benin \\
\hline $13-8$ & 4.2561 & Akangba & 1.0363 & Ikeja West & 3.6871 & Omotosho \\
\hline $13-5$ & 9.256 & Ayede & 12.3477 & Ajaokuta & 12.3477 & Benin \\
\hline $13-18$ & 9.8673 & Sapele & 13.8204 & Sapele & 22.6256 & Sapele \\
\hline $14-13$ & 7.1047 & Aja & 10.776 & Ajaokuta & 10.7761 & Benin \\
\hline $15-13$ & 2.6304 & Ajaokuta & 8.2326 & Ajaokuta & 8.23255 & Benin \\
\hline $15-17$ & 5.4213 & Aja & 3.4523 & Sapele & 24.0364 & Aladja \\
\hline 16-13 & 4.6151 & Aladja & 8.6404 & Aladja & 21.9803 & Aladja \\
\hline $16-17$ & 1.5931 & Aja & 7.9062 & Aladja & 5.8227 & Benin \\
\hline $18-20$ & 7.0294 & New Haven & 10.6699 & New Heaven & 15.7524 & Okpai \\
\hline 19-18 & 2.5873 & Benin & 2.5873 & Benin & 4.1100 & Alaoji \\
\hline $21-22$ & 3.8533 & Onitsha & 5.7873 & Ajaokuta & 6.8982 & Onitsha \\
\hline $22-18$ & 10.8159 & Alaoji & 13.9714 & Alaoji & 25.4175 & Alaoji \\
\hline $23-3$ & 4.1506 & JebbaTs & 2.496 & Shiroro & 5.2994 & Shiroro \\
\hline $23-24$ & 3.5248 & Katampe & 5.5056 & Katampe & 7.45595 & Katampe \\
\hline $23-25$ & 5.1388 & Kaduna & 5.1385 & Kaduna & 9.67325 & Kaduna \\
\hline $25-26$ & 4.8543 & Kano & 6.7731 & Kano & 7.7021 & Kano \\
\hline $25-27$ & 4.386 & Jos & 6.3477 & Jos & 7.695 & Jos \\
\hline $27-28$ & 2.9706 & Gombe & 4.022 & Gombe & 4.552 & Gombe \\
\hline
\end{tabular}

Note: Black $=$ Low current $(\mathrm{LC})$, Blue $=$ Medium current $(\mathrm{MC}) ;$ Yellow $=$ High Current $(\mathrm{HC})$

Table 3.4: Maximum line current caused by SLG, LL, DLG and Location when $Z_{\mathrm{f}}=\mathrm{j} 0$

\begin{tabular}{|c|c|c|c|c|c|c|}
\hline From - To bus & $S L G(p u)$ & Location & $L-L(p u)$ & Location & $D L G(p u)$ & Location \\
\hline $1-2$ & 5.7715 & BirninKebbi & 8.0049 & BirninKebbi & 8.521 & BirninKebbi \\
\hline $3-1$ & 7.638 & Kainji & 8.6994 & Kainji & 9.9115 & Kainji \\
\hline $4-3$ & 11.8103 & JebbaTs & 15.5621 & JebbaTs & 16.6508 & JebbaTs \\
\hline $5-3$ & 6.7635 & Osogbo & 9.876 & Osogbo & 10.3859 & Osogbo \\
\hline $6-5$ & 8.0217 & Ayede & 10.7309 & Ayede & 11.4168 & Ayede \\
\hline $7-6$ & 5.0456 & Ikeja West & 7.2605 & Ikeja West & 7.5195 & Ikeja West \\
\hline $8-6$ & 8.4356 & Ayede & 11.1363 & Ayede & 11.921 & Ayede \\
\hline $8-7$ & 4.6136 & Ayede & 7.2019 & Ayede & 7.4139 & Ayede \\
\hline $8-5$ & 16.4218 & Papalanto & 22.3493 & Papalanto & 23.6863 & Papalanto \\
\hline $8-9$ & 8.5826 & Akangba & 11.5117 & Akangba & 12.184 & Akangba \\
\hline $10-8$ & 8.4808 & Ikeja West & 10.8965 & Ikeja West & 11.4524 & Ikeja West \\
\hline $10-11$ & 9.4079 & Aja & 13.2802 & Aja & 13.962 & Aja \\
\hline $12-8$ & 6.5397 & Omotosho & 8.2427 & Benin & 8.5784 & Benin \\
\hline $12-13$ & 7.0578 & Benin & 5.981 & Omotosho & 6.5929 & Omotosho \\
\hline $13-10$ & 6.4179 & Egbin & 9.3047 & Egbin & 9.759 & Egbin \\
\hline $13-8$ & 2.9694 & Ikeja West & 4.0802 & Ikeja West & 4.270 & Ikeja West \\
\hline $13-5$ & 6.2546 & Osogbo & 8.7459 & Osogbo & 9.2419 & Osogbo \\
\hline $13-18$ & 16.4639 & Sapele & 24.5083 & Sapele & 25.4906 & Sapele \\
\hline $14-13$ & 7.2072 & Benin & 10.4319 & Benin & 10.8361 & Benin \\
\hline $15-13$ & 5.590 & Benin & 7.9602 & Benin & 8.2957 & Benin \\
\hline $15-17$ & 15.7491 & Aladja & 22.8129 & Aladja & 23.8742 & Aladja \\
\hline
\end{tabular}

\section{Volume 5 Issue 1, January 2016}


International Journal of Science and Research (IJSR)

ISSN (Online): 2319-7064

Index Copernicus Value (2013): 6.14 | Impact Factor (2014): 5.611

\begin{tabular}{|c|c|c|c|c|c|c|}
\hline $16-13$ & 14.4491 & Aladja & 20.8551 & Aladja & 21.8356 & Aladja \\
\hline $16-17$ & 1.5684 & Sapele & 3.2814 & Sapele & 2.9961 & Sapele \\
\hline $18-20$ & 10.5221 & Okpai & 14.2337 & Okpai & 17.5902 & Okpai \\
\hline $19-18$ & 2.79635 & Alaoji & 3.83995 & Alaoji & 4.18085 & Alaoji \\
\hline $21-22$ & 5.362 & Onitsha & 6.6105 & Onitsha & 6.83945 & Onitsha \\
\hline $22-18$ & 17.3628 & Alaoji & 24.1392 & Alaoji & 23.7693 & Alaoji \\
\hline $23-3$ & 5.7098 & JebbaTs & 7.9588 & JebbaTs & 4.19125 & JebbaTs \\
\hline $23-24$ & 4.77465 & Katampe & 6.762 & Katampe & 7.10515 & Katampe \\
\hline $23-25$ & 7.0505 & Kaduna & 8.9056 & Kaduna & 9.29395 & Kaduna \\
\hline $25-26$ & 5.3429 & Kano & 7.1218 & Kano & 7.4349 & Kano \\
\hline $25-27$ & 5.1403 & Jos & 6.893 & Jos & 7.3189 & Jos \\
\hline $27-28$ & 3.2031 & Gombe & 4.1324 & Gombe & 4.386 & Gombe \\
\hline
\end{tabular}

Red $=$ Available maximum current (AMC)

\subsection{Evaluation of Technical Power Loss on the Power Line Test System}

Here, the calculation of technical power losses is carried out on the power line test system i.e the Nigerian $330-\mathrm{kV}$ transmission system, using the results obtained in tables3.3 and based on the established peak line currents for both average (LC/MC) and maximum (HC/AMC) line current magnitudes.

Typical Base Values at 100MVA Base for the Nigerian 330-kV System

$$
\begin{gathered}
V_{b}=\frac{V_{L}}{\sqrt{3}}=\frac{330 \times 10^{3}}{\sqrt{3}}=190.5255 \mathrm{kV} \\
\mathrm{I}_{b}=\frac{M V A_{b}}{3 V_{b}}=\frac{100 \times 10^{6}}{3 \times 190.5255 \times 10^{3}} \\
=174.9546 \mathrm{~A} \text { or } 0.175 \mathrm{kA}
\end{gathered}
$$

$R_{b}=\frac{V_{b}}{\mathrm{I}_{b}}=\frac{190.5255 \times 10^{3}}{174.9546}=1089 \Omega$

Using the above base values, the pu line current magnitude and line resistance are converted to their actual values. Thus, the power losses for LC, MC, HC and AMC are computed using equation 3.1 .

$$
\mathrm{P}=\mathrm{I}^{2} \mathrm{R}
$$

The power losses for the various categories are calculated. Therefore, these power losses in the power line test system for $\mathrm{LC}, \mathrm{MC}, \mathrm{HC}$ and $\mathrm{AMC}$ are presented as $146.73 \mathrm{MW}$, $323.24 \mathrm{MW}, 737.79$ and $738.77 \mathrm{MW}$ respectively. The graphical representations of the power losses calculated for $\mathrm{LC}, \mathrm{MC}, \mathrm{HC}$ and AMC are shown in figure 3.2.

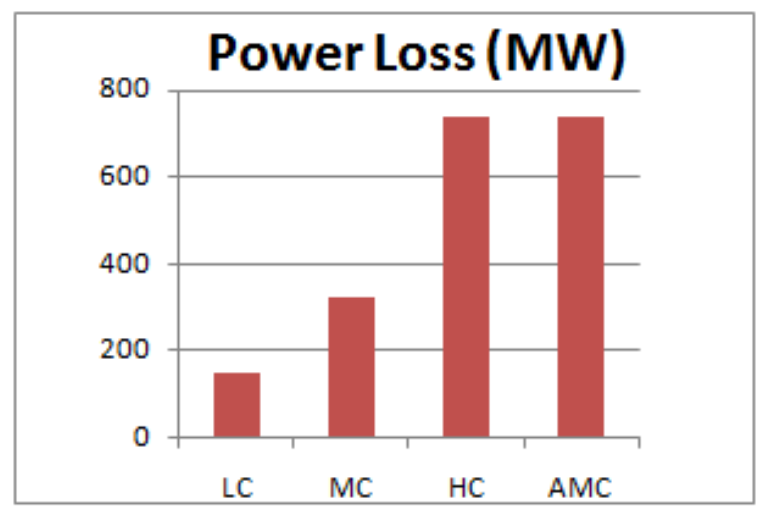

Figure 3.2: Power losses calculated for $\mathrm{LC}, \mathrm{MC}, \mathrm{HC}$ and AMC

It can be seen in figure 3.2, that the equality of $\mathrm{HC}$ and $\mathrm{AMC}$ is confirmed and that is a justifiable approximation of equality. Therefore, the average of the $\mathrm{HC}$ and $\mathrm{AMC}$ which is $738.28 \mathrm{MW}$ is considered as the possible available peak loss in the power line test system. Now for this study, there are three categories of power loss level determined to be associated with the power line test system. These are;

- Low power line loss is 146.73MW obtained from LC

- Medium power line loss is 323.24MW obtained from MC

- High power line loss is738.28MW obtained from $\mathrm{HC} / \mathrm{AMC}$

The three power loss level scenarios are likened to the trio of steady-state, sub transient and transient situation.stages of a fault.

\subsection{Annual Loss Estimation of Low, Medium and High Power Line Losses}

Estimation of annual power line losses of the test system is carried out based on the results of the three power loss levels shown in figure 3.2above. Since these results are obtained at their maximum peak current, there is the necessity to have the knowledge of the test system daily peak demand or peak load in order to determine the actual point of peak demand which is part of the parameter needed to calculate the annual power line losses. It should be noted that the maximum demand or peak demand dictates the size of transmission lines for utilities even if that amount lasts just one hour per year [12]. The peak load data for the period (January 2013 - December 2013) are tabulated as shown in table 3.5. The data are inputted 


\section{International Journal of Science and Research (IJSR) \\ ISSN (Online): 2319-7064 \\ Index Copernicus Value (2013): 6.14 | Impact Factor (2014): 5.611}

into the HOMER simulation software [13]. Figure 3.4 shows the hourly average load variation for the Nigerian $330-\mathrm{kV}$ transmission lines (test system). The peak load of
$4950 \mathrm{MW}$ is as indicated in figure 3.3 and the daily average energy of $3754.69 \mathrm{MW}$ is computed from table 3.5 .

Table 3.5: Daily peak demand of the test transmission system (January 2013-Dec. 2013)

\begin{tabular}{|c|c|c|c|c|c|c|c|c|c|c|c|c|}
\hline Hour & 3 & 1 & 13 & 1 & 13 & 13 & 13 & 13 & 13 & 13 & 13 & 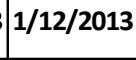 \\
\hline 0.0 & 0 & 0 & & 0 & 00 & 00 & 00 & & 3250.00 & & & 500 \\
\hline & & & & & & & & & & & & \\
\hline & & & & & & & & & & & & \\
\hline 3.0 & 0.00 & 0 & & & 00 & .00 & .00 & & & & & 80 \\
\hline & .00 & 0.00 & & 1 & & .00 & & & & 0.0 & & \\
\hline & & & & & & & & & & & & \\
\hline & & & & & & & & & & & & \\
\hline 7.0 & .00 & & & & & .00 & 00 & & & .0 & & .0 \\
\hline & & & & & & & & & & & & \\
\hline & & & & & & & & & & & & \\
\hline 1.00 & .00 & .00 & .00 & & 00 & .00 & .00 & & & & & 5.0 \\
\hline & .00 & .00 & & & & & & & & & & \\
\hline & & & & & & & & & & & & 0.0 \\
\hline & & & & & & & & & & & & 0.0 \\
\hline & 7.00 & 0 & & & & & & & & & & 0.6 \\
\hline & & & & & & & & & & & & 5.0 \\
\hline & & & & & & & .00 & & & & & 0.0 \\
\hline 17.0 & 0.00 & 200.00 & 5.00 & 4150.00 & 0.00 & 0.00 & 5.00 & & & & & 50.0 \\
\hline & .00 & 0.00 & 0.00 & 0.00 & 0.00 & 0.00 & 0.00 & .00 & & .00 & & $0 .($ \\
\hline & & & & & & & & & & & & 0 \\
\hline 20. & 0.00 & 0.00 & .00 & .00 & 0.00 & 0.00 & 5.00 & 0.00 & 00 & 0.00 & 0.00 & 00.0 \\
\hline & & & & & & & & & & & & 0.4 \\
\hline & & & & & & & & & & & & 0. \\
\hline .00 & 3900.00 & 4050.00 & 4200.00 & $41 \angle 0.00$ & 3700.00 & 3800.00 & $3 / 00.00$ & 3250.00 & $34 \angle 5.00$ & 3200.00 & 3450.00 & 3500.0 \\
\hline
\end{tabular}

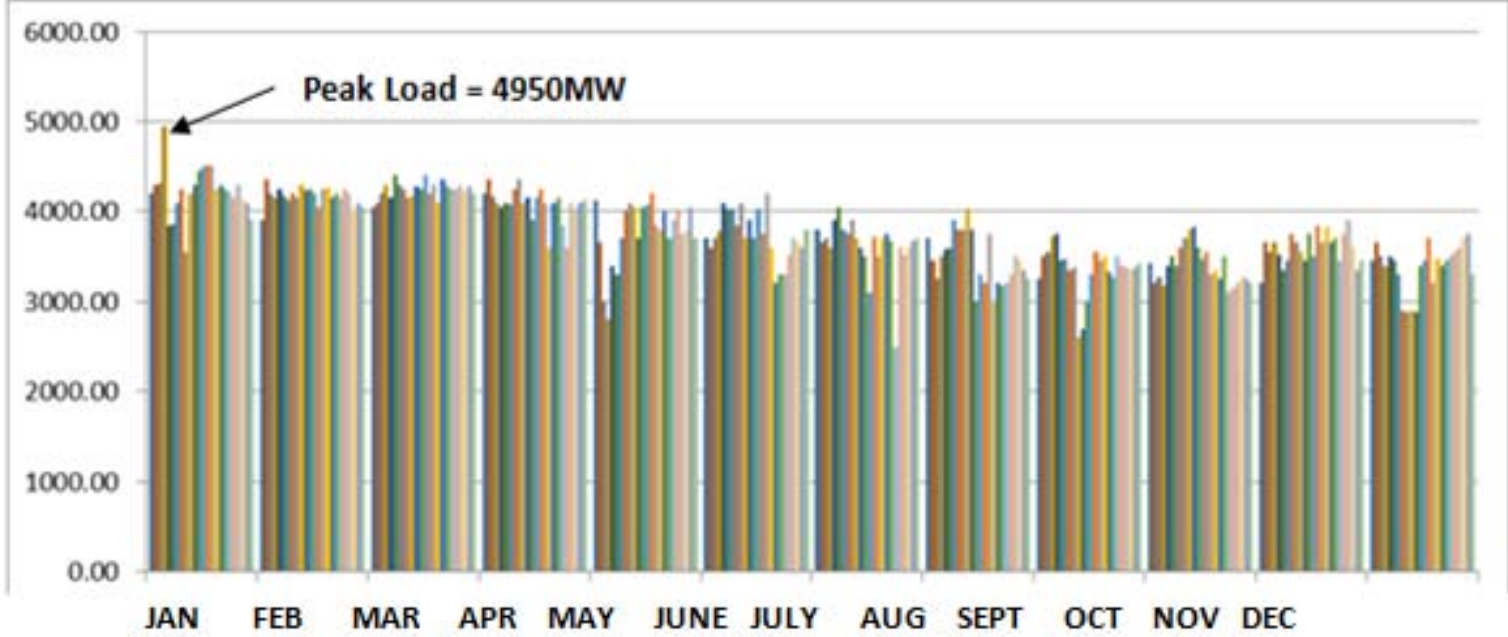

Figure 3.3: The daily peak demand load (January 2013 - December 2013)

Volume 5 Issue 1, January 2016 www.ijsr.net 


\section{International Journal of Science and Research (IJSR) \\ ISSN (Online): 2319-7064}

Index Copernicus Value (2013): 6.14 | Impact Factor (2014): 5.611

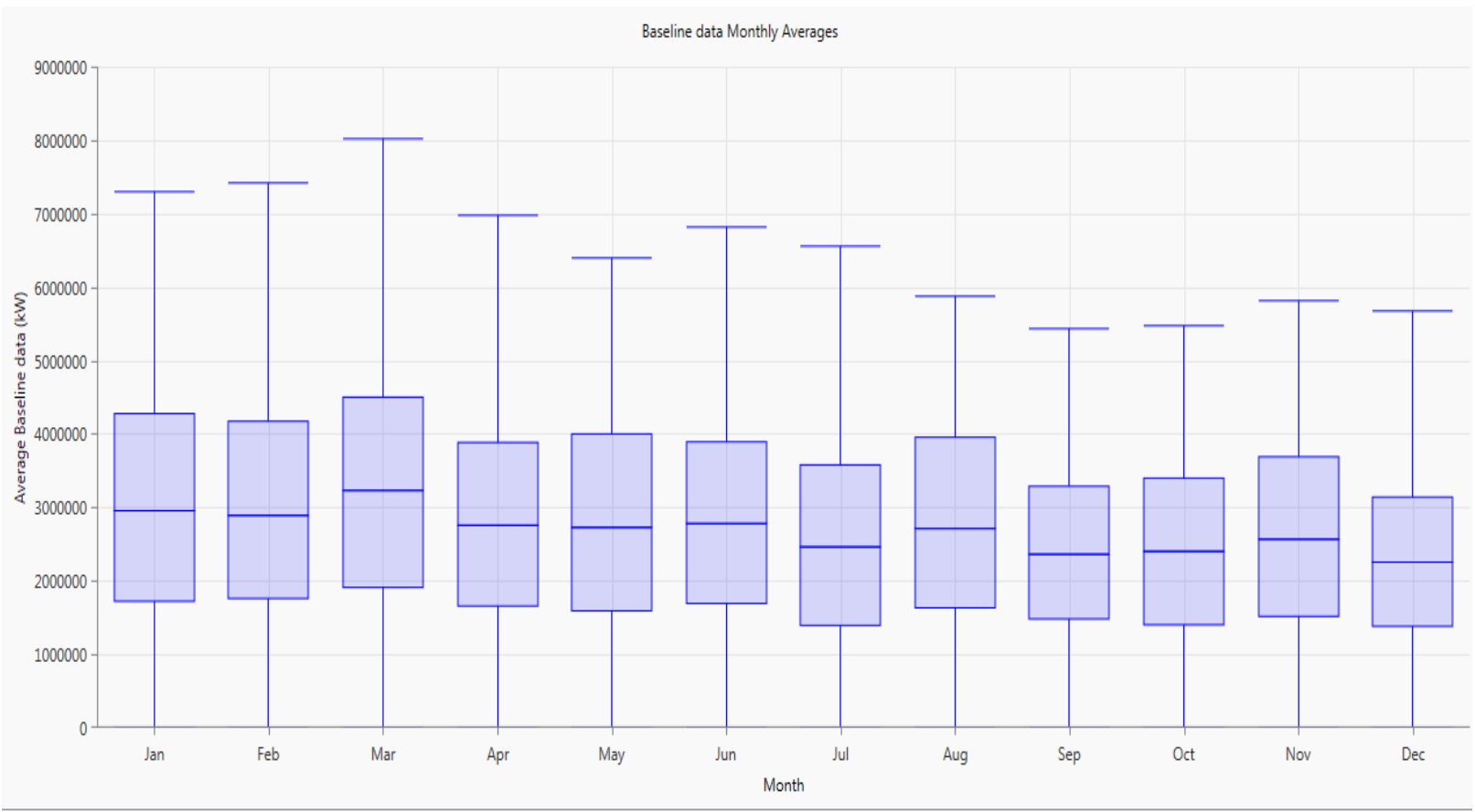

Figure 5: The monthly average load plot (January 2013 - December 2013)

From the result obtained in the simulation of peak load and average load under peak transmission line (test system) for January 2013 - December 2013, the total loss is obtained as follows: The daily load factor is given based on hourly load reading as

Daily load Factor $($ DLF $)=\frac{\text { Average load in } 24 h}{\text { Peak load in } 24 h} 3.2$

Load factor may be given for a day, a month, or a year. The yearly or annual LF is the most useful since a year represents a full cycle of time. Thus, the annual LF is given as

Annual load Factor $(\mathrm{ALF})=\frac{\text { total annual energy }}{\text { Peak load } \times 8760 \mathrm{hr}} 3.3$

In this study, the annual load factor (ALF) is estimated from the average load by using the hourly average load variation for January 2013 - December 2013.

Thus, the ALF is obtained as

$\mathrm{ALF}=\mathrm{DLF} \times \mathrm{R}_{\mathrm{AD}} \times \mathrm{R}_{\mathrm{AM}}[14] 3.43 .4$

Where

$$
\begin{aligned}
& \mathrm{ALF}=\text { Annual Load Factor } \\
& \mathrm{DLF}=\text { Daily load Factor } \\
& \mathrm{R}_{\mathrm{AD}}=\frac{\text { Average daily peak load }}{\text { Mont hly Peak load }} 3.5 \\
& \mathrm{R}_{\mathrm{AM}}=\frac{\text { Average mont hly peak load }}{\text { Annual Peak load }}
\end{aligned}
$$

From the hourly readings of table 6 , the peak load is $4950 \mathrm{MW}$ as indicated in figure 4 and daily average load is 3754.69 as calculated from table 3.5

Using equation 3.2 above, DLF is

$\mathrm{DLF}=\frac{\text { Average load in } 24 h}{\text { Peak load in } 24 h}=\frac{3754.69}{4950}=0.759$

The average daily peak load for January - December 2013 is $3812.08 \mathrm{MW}$ with monthly peak load of $4950 \mathrm{MW}$ in January.

Thus, using equation 3.5

$\mathrm{R}_{\mathrm{AD}}=3812.08 / 4950=0.770$

Also from figure 3.4,

The average monthly peak load $=4400 \mathrm{MW}$ and the annual peak load $=4950 \mathrm{MW}$.

Thus, using equation $6 ; \mathrm{R}_{\mathrm{AM}}=4400 / 4950=0.889$

Therefore, using equation 4.3, annual load factor (ALF) is given as

$\mathrm{ALF}=0.759 \times 0.770 \times 0.889=0.52$

The Load Loss Factor (LLF) required for annual energy calculation is given as

$\mathrm{LLF}=\mathrm{K} \times \mathrm{ALF}+(1-\mathrm{K}) \times(\mathrm{ALF})^{2}[15] 3.7$

where $\mathrm{K}$ means proportioning multiplier in the LLF equation 7 ;

where $0<\mathrm{K}<1$ and $\mathrm{K}$ is normally 0.3 for transmission line. 
Using equation 3.7 ;

$\operatorname{LLF}=0.3(0.52)+0.7(0.52)^{2}=0.345$

Using the Loss Load Factor (LLF) of 0.345, the annual energy for the three categories of power loss evaluated in this study can be estimated as

\section{$>$ Annual MWH Loss for 146.73MW (Low Power Loss Level): \\ $=\mathrm{LLF} \times($ peak loss in $\mathrm{MW}) \times 8760.3 .8$}

Using the maximum power loss of 146.73MW obtained in the course of this work; the total energy loss for year 2013 is estimated as

$=0.345 \times 146.73 \times 8760$

$=443447.41 \mathrm{MWH}$ or $443.45 \mathrm{GWH}$

\section{$>$ Annual MWH Loss for 323.24MW (Medium Power Loss Level):}

Using equation 8 and the maximum power loss of 323.24MW obtained in the course of this work as medium power loss level; the total energy loss for the year 2013 is estimated as

$=0.345 \times 323.24 \times 8760$

$=976895.93 \mathrm{MWH}$ or $976.895 \mathrm{GWH}$

\section{$>$ Annual MWH Loss for 738.28MW ( High Power Loss Level):}

Using equation 8 and the maximum power loss of $738.28 \mathrm{MW}$ obtained in the course of this work as high power loss level; the total energy Loss for the year 2013 is estimated as

$=0.345 \times 738.28 \times 8760$

$=2231229.82 \mathrm{MWH}$ or $2231.230 \mathrm{GWH}$

\subsection{Cost Implications}

The total amount of financial loss in the estimated annual energy loss of section 3.4 is evaluated for each of the power loss levels - Low, Medium and High power losses. The cost evaluation is based on the Naira/KWH energy rates for Eko district, under the new power tariff MYTO 2 for 2013/2014 [16]. The cost of energy is rated at N19 per KWH or N19000/MWH, by taking the average of all the tariff class energy unit costs $(\mathrm{N} / \mathrm{KWH})$. Using the $\mathrm{N} 19000 / \mathrm{MWH}$, the annual financial loss due to each power loss level associated with the $330-\mathrm{kV}$ power lines is estimated as follows:

$>$ For the Low Power Line Loss with annual loss of 443447.41MWH, the annual financial loss for the year 2013 is $443447.41 \mathrm{MWH} \times \mathrm{N} 19000 / \mathrm{MWH}$

i.e. N8, 425,500,790; approximately amounted to $\mathbf{8 . 4}$ billion Naira
$>$ For the Medium Power Line Loss with annual loss of 976895.93MWH, the annual financial loss for the year 2013 is $976895.93 \mathrm{MWH} \times \mathrm{N} 19000 / \mathrm{MWH}$

i.e. N1.86 $\times 10^{10}$; approximately amounted to18.6 billion Naira

$>$ For the Low power line loss with annual loss of 2231229.82MWH, the annual financial loss for the year 2013 is $2231229.82 \mathrm{MWH} \times \mathrm{N} 19000 \mathrm{MWH}$

i.e. N4.24 $\times 10^{10}$; approximately amounted to $\mathbf{4 2 . 4}$ billion Naira

\section{Conclusion}

In this study, the evaluation of technical losses-steady and transient phenomena was captured successfully on Nigeria $330-\mathrm{kV}$ transmission network. Three levels (i.e low, medium and high) of maximum line current were determined and used accordingly to calculate the three categories of power loss level associated with the network which in turn was used to estimate the annual power line losses for the year 2013 using the peak load data for the period (January2013 - December2013). The annual loss energy for the year 2013 and the huge financial drain in the network were identified and quantified;the low, medium and high energy losses were respectively found to be $443.45 \mathrm{GWH}$, 976.895GWH and 2231.230GWHamounting to financial losses of N8.4 billion, N18.6 billion and N42.4 billion respectively.

The results of the load-flow analysis that were performed using MATLAB and PWS compared favourably well with the $146.73 \mathrm{MW}$ power loss obtained at steady-state in this work. Also, it validated the results of $2231.23 \mathrm{GWH}$ losses obtained in the work with the normal practice of PHCN energy balance (as shown in table 2.1)thereby closing the gap between the practical information and the theoretical one and also it optimizes the loss level which results in a high degree of accuracy.

\section{Acknowledgement}

The author is highly indebted to Power Holding Company of Nigeria (PHCN) for providing relevant data necessary for power-flow study and the peak load demand data for the period (January 2013-December 2013.

\section{References}

[1] PHCH, 2003National Control Centre Oshogbo.(2004). Generation and Transmission GridOperations. AnnualTechnical Report for 2003.

[2] PHCN National Control Centre Oshogbo. (2005).Generation and Transmission Grid Operations.Annual Technical for Report 2004.

[3] Pabia, A. S., 2013. Electric Power Distribution (4th Edition), 6th; Reprint, Tata McGraw-Hill Publication Com. Ltd. New Delhi

[4] IEA (2013), Key World Energy Statistics $s 2013$ [online] available: 


\section{International Journal of Science and Research (IJSR) \\ ISSN (Online): 2319-7064}

Index Copernicus Value (2013): 6.14 | Impact Factor (2014): 5.611

http://www.iea.org/publications/freepublications/publi cation/KeyWorld2013.pdf\{accessed 31/05/2014\}

[5] Gaspar, Viera (2011). "Electrical Annual EnergyLosses Determination in Low Voltage ACaseStudy". RevistaEletronica Sistemas \& Gestao,91-116 vol. 6.

[6] Wadwah, C. (2006). Electric Power system.Chennai: New Age International Publisher Limited.

[7] Glover, J. D and Sarma, 2002. Power System Analysis and Design. ( $3^{\text {rd }}$ Edition), Wadsworth Group, Brooks Cole, a division of Thomson Learning Centre

[8] ONEM. (2011). "The Electricity market Operations, January - December 2010" theMarketOperations report. Transmission Company of Nigeria.

[9] PHCN NCC ANNUAL REPORT. (2009). Generation, Transmission and Distribution Grid Operations. National Control Centre (NCC) Oshogbo.

[10] Power Holding Company of Nigeria (PHCN). (2013). "Network Data of the Nigerian 28-bus Power System; National Control Centre (NCC)". Oshogbo.

[11] Power World Co-operation. ((2014 Version)). Power World Simulator, Version 18 Glover/Sarma Build11/02/01, Licensed only forEvaluation and University Education use.

[12] Lowel. (2006). Energy Utility Rate Setting . Retrieved June 25th, 2013, from ulu.com.p.66.ISBN 1411689593 :

[13] HOMER Pro 3.1. (n.d.). National Renewable Energy Laboratory (NREL)Retrieved from617 Cole Boulevard Golden, CO 80401-3393: http:/www.nrel.gov/homer

[14]IEEE Standard Board. (1997). "IEEE RecommendedPractice for Industrial and Commercial Power SystemsAnalysis". Approved by American National Standard Institute, (IEEE Std 399-1991).

[15]Electricity Authority, Te Mana Hiko. (2013).Annual Energy Report .www.parliament.nz/.../electricityauthority-te-mana-hiko-annual-report-2...

[16]PHCN Eko Distribution Company. (2013/2014, February 3rd). 2013 New Energy Tariff \&Cost for EkoDistrict. Retrieved February 16th, 2014, from Power Tariff under MYTO 2 for 2013/2014 